\title{
Influence of Life Events on the Financial Satisfaction of Individuals
}

\author{
Waqas Ali $^{1 *}$ \\ Rehman Javaid ${ }^{2}$ \\ Shujahat Ali \\ Yasir Akram $^{4}$ \\ Ayaz $\mathrm{Ul} \mathrm{Haq}$
}

\begin{abstract}
This study aims to determine the effect of financial knowledge and financial socialization on the financial satisfaction of the individuals when unexpected life events happen and to examine themediating role of the financial stressor and financial behavior between them. The data collected from 243 respondents whohad experienced any unexpected hospitality in the state of Azad Jammu and Kashmir. Grab sampling method utilized for data collection. Confirmatory factor analysis (CFA) and Structura Equation Modeling (SEM) utilized for data analysis. Results of study reveal that: 1) financial knowledge and financial socialization have positive influence on financial satisfaction; 2) financial knowledge has positive effect on financial satisfaction with the mediating role of the financial stressor and financial behavior when an unexpected life event happens; and 3) financial socialization has positive effect on financial satisfaction with the mediating role of the financial stressor and financial behavior when an unexpected life event happened. This study provides clear insight toward the financial satisfaction of the individuals while confronting the unexpected life events. Practitioners and financial planners use this article for increasing the financial satisfaction of their customers. There is plethora of researches conducted in different perspective except life events of individuals. This study utilized confirmatory factor analysis, which is necessary when research carried out from a different perspective.
\end{abstract}

Keywords: Financial Stressor, Financial Socialization, Financial knowledge, Financial Behavior, Financial Satisfaction.

1- Limkokwing University of Creative Technology, Cyberjaya, Malaysia, email: waqas_ali1125@, yahoo.com

2- Limkokwing University of Creative Technology, Cyberjaya, Malaysia, email: rahmanjavaid@, hotmail.com

3- Mirpur University of Science and Technology, Mirpur A.K, email: shujahat@must.edu.pk

4- The Limkokwing University of Creative Technology, Cyberjaya, email: yasirakramarain@, yahoo.com

5- University of Central Punjab, Rawalpindi Campus drayazulhaq16@gmail.com 
IBT Journal of Business Studies Volume 15(1), 2019

\section{INTRODUCTION}

In recent decades, financial satisfaction has captured much attention of researchers, scholars, and practitioners in the field of public policy analysis and individual decision-making as well as in the realm of family financial planning (Costa, Carvalho, \& Moreira, 2019). Itis crucial to understand the level of financial satisfaction of peoples, as itcan help policymakers to enhance the level of satisfaction of people. Financial satisfaction is a basic component of happiness, which results from diligent efforts made by someone. The word financial satisfaction derived from an individual's behavior, which linked to diligent efforts, made in the form of managing their revenues for the fulfillment of financial needs. Financial satisfaction is a fundamental element of life satisfaction. Conclusively, a financial satisfied person is the person with positively satisfied with his or her life.

Subjective norm and social bounding trigger individuals' behaviors. They calculate risk and avoid risk in the matter of financial division making (Ali, Lu, \& Wang, 2013). Financial satisfaction is an essential element of financial wellbeing (Norvilitis, Szablicki, \& Wilson, 2003) which is linked to psychological wellbeing (Archuleta, Dale, \& Spann, 2013). The term financial wellbeing also has much attention in the recent decades due to the emergence of financial crisis that pushed countries into recession, concerning issues related to financial wellbeing discussed (Ranta, Chow, \& SalmelaAro, 2013). The most emerging issue is the financial situation of individuals. For example, young Malaysian employees face financial situation, for example, rising cost of living, which influence $s$ the wellbeing of individuals (CFBP, 2015)Studies (for example (Ruxyn, 2017) suggest that most of the individuals are incapable ofmaking a financial decision for their wellbeing.

In the past decades plethora of studies laid emphasis onmeasuring financial satisfaction in different perspectives (Joo \& Grable, 2004; Kalra Sahi, 2013; Newman, Delaney, \& Nolan, 2008; Power \& Hira, 2004; Sahi, 2017; Saurabh \& Nandan, 2018; Xiao, Sorhaindo, \& Garman, 2006). These studies examined different factors such as socio-economic factors, financial knowledge, financial socialization, and financial stressor's influence on financial satisfaction of individuals and so on. However, there is nooneof the studies, to the best of the authors' knowledge, has studied the financial satisfaction of any individual in a situation when they have confronted any specific event such as marriage and hospitality. Additionally, the past studieshave largely ignored the lower middle class, which considered more vulnerable in the society. Moreover, the direction of such kind of relationship between the predictors and financial satisfaction not well established yet.

World Bank (2019) statistics also show that the gross domestic saving of the country has declined from 17.61 in 2004 to just $6.8 \%$ in 2018. A fall in the gross domestic saving result in changes in household structure, increased energy cost, decreased spending power and, increased unemployment. Erosion in the domestic savings of families, causes distress among families and weakens joint family system (Saurabh \& Nandan, 2018), This situation is likely to be aggravated, when families have to confront unexpected hospitality. Since Pakistan has experienced substantial decline in the gross domestic savings, there is a need to study the financial satisfaction of the Pakistani peoples in situations when they confront unexpected hospitality.

To find out factors, which significantly influence on financial satisfaction, are financial knowledge, financial stressor, financial behavior, and the financial socialization. Studies determined the inconsistencies between the financial socialization and financial knowledge on financial satisfaction, but some studies found consistent. These consistencies depend on the cultural or socio-economic difference of the respondents. There are very few studies, which have attempted to check mediating 
effect of both variables' financial stressor and financial behavior on the financial satisfaction of individuals. There are also very few studies which have been conducted in developing countries. Besides, the previous studieshave also ignored lower class, which considered a vulnerable class in every society. Theobjectives of this paper are to determine the effect of financial socialization and financial knowledge on financial satisfaction, and to examine the mediating role of financial behavior and financial stressor while the individuals confront unexpected hospitality.

\section{LITERATURE REVIEW}

\section{Financial Knowledge and Financial Satisfaction}

According to the Oxford dictionary, "financial knowledge is the awareness about some things such as facts, information and skills which obtained from the experience, learning and from education" (Dictionary). Financial knowledge referred to fundamental grip of financial conceptualization or financial methods. By utilizing financial concepts and methods, an individual can solve financial problems more effectively and efficiently (Delgadillo \& Law, 2019). There are two elements of financial knowledge such as objective financial knowledge and subjective financial knowledge. Objective financial knowledge is the existing financial knowledge of individuals. It is the combination of existing and new knowledge. The subjective knowledge states the confidence of individuals to make financial decision effectively and efficiently (Wang, 2009). The present study, places focus on the only subjective financial knowledge.

Financial satisfaction is defined as someone's present financial situation (Gerrans, Speelman, \& Campitelli, 2014). It is a fundamental component of financial wellbeing (Norvilitis et al., 2003). There are numerous studies on themeasurement of financial satisfaction (Kalra Sahi, 2013; Kirbiš, Vehovec, \& Galić, 2017; Xiao, Chen, \& Chen, 2014; Xiao \& O’Neill, 2018; Xiao \& Porto, 2017; Yong, Yew, \& Wee, 2018).

Most of the prior studies utilized financial knowledge as predictor of financial wellbeing of individuals such as Archuleta et al. (2013), financial satisfaction (Saurabh \& Nandan, 2018), diversification (Calvet, Campbell, and Sodini (2007), and financial distress (Lajuni, Bujang, Karia, \& Yacob, 2018). Only few studies have shownthe effect of financial knowledge on financial satisfaction as positive (Xiao et al. (2014). Some studies have reported negative relationship between them (Mugenda, Hira, \& Fanslow, 1990).

H1: Financial Knowledge has a positive effect on financial satisfaction when an unexpected event has happened.

\section{Financial Knowledge and Financial Stressors}

A financial stressor is a kind of unpleasant feeling which is based on not fulfilment of elementary necessities of life and financial obligations (Davis \& Mantler, 2004). It does have a psychological effect (Northern, O’Brien, \& Goetz, 2010). According to Kirbiš et al. (2017) a financial stressor is a major component of financial satisfaction and financial knowledge. It is a kind of life cycle event. Those peoples with more rational financial behavior faced more financial stress. Financial stress does not only influence individuals but also affect family life. Financial stress may also come from the family, relatives, and friends.

A major cause of financial stressor is lack of knowledge and rational financial behavior of individuals. It adversely affects financial satisfaction. According to APA (2012) approximately 69\% of the stress 
IBT Journal of Business Studies Volume 15(1), 2019

of adults comes from financial issues. Financial stressor causes depression and anxiety (Andrews and Wilding (2004), bad academic performance (Harding (2011) and ill effects on the health of individuals (Northern et al., 2010). There are approximately 18-44\% household face some kind of financial stress (Marks (2007) in Australia. Moreover, both low-income households and higher income households experience financial stress (Bray (2001).

H2: Financial kknowledge has a positive effect on financial stressor when an unexpected event happened.

\section{Financial Knowledge and Financial Behavior}

According to Xiao (2008), financial behavior is any human behavior which is related to money management. Financial behavior utilized for any specific purpose of research in which mostly are not exhaustive. Li, Subrahmanyam, and Yang (2018) Outcome of financial knowledge are the products offered do create behavioral biases. Gerstenecker, Triebel, Eakin, Martin, and Marson (2018) Monetary knowledge and skill drive the behaviors of utilization existing resources and planning. Timmer (2018) Knowledge about the security of instrument tigers the behavior either to invest or not. Hsiao and Tsai (2018) Individuals at higher levels of financial knowledge are known to be better decision makers and having strong behavioral control. Hence Lanlan, Xuesong, and Rong (2018) proved by the role of knowledge significant contributor to build and guide the financial behavior

H3: Financial knowledge is the driver of the financialbbehavior.

\section{Financial Socialization Financial Satisfaction}

Socialization starts from the childhood of individuals and continues throughout life. Individuals gain different skills and knowledge from society through the procedure of socialization. It is the procedure to gain the knowledge and skills, which contribute to the wellbeing of society. There are visible differences in financial socialization and satisfaction of different people. Agnew, Maras, and Moon (2018) Confirmed variation in male and females' financial satisfaction. Xiao and O'Neill (2018) Revealed that there are differences in propensity to plan based on socio-economic experiences and propensity to plan, whichaffect decisions. Experimental learning is vital for financial satisfaction LeBaron et al. it applies across major stakeholders in society parents, researchers, and educators. financial socialization and financial knowledge are positively influenced on the wellbeing of society (Falahati \& Paim, 2011). Based on the above literature, we concluded that the level of financial socialization influences the financial decisions. Moreover, such decisions do affect financial satisfaction.

H4: Financial socialization increases financial satisfaction.

\section{Financial Socialization and Financial Behavior}

In the current era, most of the researchers of behavioural finance grab the attention of financial socialization because this is considering the root cause of decreasing personal savings. Parents considered the most influenced actors of socialization process. In the financial perspective, parents influenced in three ways:first, is modeling of the behaviors second is rules and monitoring and the third is one to one communication. Humans knew to be social entities. They learn to educate and respond as per their social experience. As Shim, Barber, Card, Xiao, and Serido (2010) proved that in cross-sections the role of socialization was evident in financial behavior. The family "What and How" are known to be critical in all aspects of individuals life. LeBaron, Hill, Rosa, and Marks 
(2018) Proved it right in the finance behavior upbringing.

H5: Financial socialization builds up financial behavior.

\section{Financial Socialization and Financial Stressors}

Whenever individual go through the process of choice and pick, they are likely to face financial stress. However, the stress level varies with respect to gender and variety of other factors. People with more financial options feel more stress. People living in broader social circles feel more stressed as compared to those living in small communities (Hayhoe, Leach, Turner, Bruin, \& Lawrence, 2000). Individuals under debt experience a higher level of financial stress. It is associated with the failure in life as people fail in academia or life ventures (Lim, Heckman, Montalto, \& Letkiewicz, 2014). Parents with kids also face financial stress situation (Aboagye \& Jung, 2018).

H6: Financial Socialization increases the financial sstressors.

\section{Financial Stressor and Financial Satisfaction}

Financial stressor expected to impact financial satisfaction of people. It is defined as the life event which is influenced by the family, friends, and relatives (McCubbin \& Patterson, 1983). Financial satisfaction is positively associated with the increase in the anxiety among college students in United KingdomAndrews and Wilding (2004) also influenced academic performance (Joo, Durband, \& Grable, 2008). There are a plethora of studies which confirm that peoples confronting financial dissatisfaction experience financial stress (Joo \& Garman, 1998). Financial stressor would produce a negative effect on personal health of individuals, cause absenteeism from the workplace and create family issues (Kim \& Garman, 2003).

H7: Financial stress negatively affects financial satisfaction.

\section{Financial Behavior and Financial Satisfaction}

People self-worth in relationship to society. Thoughts and beliefs are the key drivers to our financial behavior (Hira \& Mugenda, 1999). Financial satisfaction is, directly and indirectly, related to factors like knowledge, information, risk and notably behavior (Joo \& Grable, 2004). Gender is a dichotomy in all societies and individual behave differently and hold variable satisfaction parameters (Hira \& Mugenda, 2000). A decision involving less risk increases the level of financial satisfaction (Xiao et al., 2014). There are more aids available to grow financial behavior that affects the productivity (Loibl \& Hira, 2005). Feelings and commitments are vital to innovate human behavior (Wikhamn, 2019). Positive connections have been identified between financial behavior and satisfaction (Totenhagen, Wilmarth, Serido, Curran, \& Shim, 2019). Financial behavior moderates with social experience that triggers spending and eventually satisfaction (Sirgy, Yu, Lee, \& Bosnjak, 2019). However, the motive is to study good financial behavior that triggers financial satisfaction.

H8: Financial behavior triggers financial satisfaction. 


\section{Research Model}

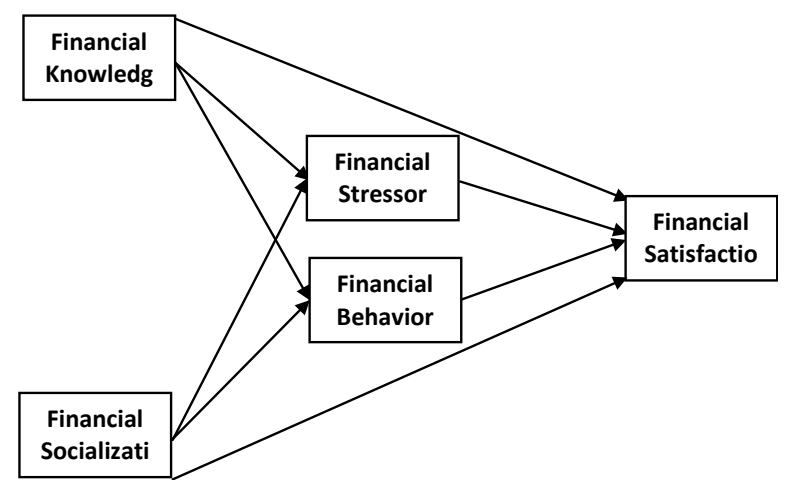

\section{METHODOLOGY}

This study employed quantitative approach.Survey method utilized to collect data from the respondents who had experienced the unexpected event such as unpredicted hospitality. This study opted the cross-sectional data collection approach. Based on literature, the conceptual model developed which shown in Figure 01 . To determine the validity and reliability, confirmatory factor analysis (CFA) and other tests used. For the checking of mediation analysis, three steps proposed by (Baron \& Kenny, 1986) were employed.

Data were analysed with SmartPLS. In the first phase of data analysis, this study checked the influence of financial knowledge on financial satisfaction in the presence of financial stressor and financial behavior. While on the second phase to determine the influence of financial socialization on financial satisfaction with the presence of financial behavior and financial stressor. In the third phase to examine the direct effect of financial knowledge and financial socialization on financial satisfaction.

This study conducted in Pakistan. Data collected from the peoples of Azad Kashmir who had confronted with unexpected hospital. According to Statistics (2017) total population of Azad Kashmir is 4.45 million and the literacy rate is $76.6 \%$. The unemployment rate is $14.4 \%$ in the state of Azad Jammu and Kashmir. Grab sampling technique was utilized for the data collection. Researchers contacted the governmental as well as the private hospitals located in the state to gather records about patients admitted in the hospitals. Before getting responses, the researcher briefed each respondent about the objectives of the study and solicited their consent to provide their responses. In total 243 people provided their responses. All of them met the criterion i.e., they had experienced unexpected hospitality.

To measure financial knowledge of individuals, the scale was adapted from Robb and Woodyard (2011) with some modifications. The scale measured responses on three points i.e., "True", "False" and "Don't Know". This scale used to determine fundamental knowledge of the respondents toward management of money. Six items scale was adapted from (Grable \& Joo, 2001) to measure financial behavior with some modifications. This scale measured responses on five-point scale i.e., "never", "seldom", "sometimes", "often" and "very often". Six-Items scale was adapted from (Hira, Sabri, \& Loibl, 2013) to measure financial socialization. It measuredresponses on five points scale i.e., "Strongly Disagree", "Disagree", "neutral", "Agree” and "strongly", Agree”. Financial satisfaction 
measured eight items adapted from (Hira \& Mugenda, 1998). It also measured responses on 5 points scale (from strongly disagree to strongly agree). Scale of financial stressor was adopted from (Grable \& Joo, 2001). It also measured responses on 5 points scale (from strongly disagree to strongly agree).

To analyze the model of current study, authors utilized partial least square (PLS) methods, which considered a second-generation analysis technique. For the data analysis, Smarts PLS version 3.2.8 was used which analyze both reflective as well formative model simultaneously (F. Hair Jr, Sarstedt, Hopkins, \& G. Kuppelwieser, 2014). This is the strongest analysis method which is used by lots of prior studies (Hussain \& Endut, 2018; Saurabh \& Nandan, 2018) also very useful for visualizing the representation of the model.

\section{ANALYSIS AND DISCUSSION}

According to demographic analysis of the respondents, $86 \%(n=209)$ of the respondents were male and remaining $14 \%(n=34)$ female. About $26 \%(n=63)$ of the participants werein the age group of 20-30 years, $46 \%(n=112)$ in $31-40$ years, $21 \%(n=51)$ in $41-50$ years and remaining $7 \%(n=17)$ in 51-60 years age group. About 38\% $(\mathrm{n}=93)$ had facedone-time unexpected hospitality, $41.6 \%$ $(\mathrm{n}=101)$ had experienced two times, $11.5 \%(\mathrm{n}=28)$ had experienced three times and remaining 8.6 $\%$ had experienced four times unexpected hospitality. About $42 \%(n=103)$ of the respondents had jobswhile $58 \%(n=140)$ had no job at the time of survey.

Table 1.

Measurement Model

Statistics of the measurement model

\begin{tabular}{|l|l|l|l|l|l|l|l|l|}
\hline $\begin{array}{l}\text { Before } \\
\text { Iteration }\end{array}$ & & & & $\begin{array}{l}\text { After } \\
\text { Iteration }\end{array}$ & & & & \\
\hline Loadings & AVE & CR & Alpha & Loadings & AVE & CR & Alpha & \\
\hline FB1 & 0.368 & & & & Omitted & & & \\
\hline FB2 & 0.530 & & & & 0.548 & & & \\
\hline FB3 & 0.807 & & & & 0.821 & & & \\
\hline FB4 & 0.737 & & & & 0.750 & & & \\
\hline FB5 & 0.383 & & & & Omitted & & & \\
\hline FB6 & 0.735 & & & & 0.781 & & & \\
\hline FB7 & 0.523 & & & & 0.508 & & & \\
\hline FB8 & 0.763 & 0.394 & 0.829 & 0.761 & 0.768 & 0.500 & 0.853 & 0.791 \\
\hline FK1 & 0.628 & & & & 0.647 & & & \\
\hline
\end{tabular}


IBT Journal of Business Studies Volume 15(1), 2019

\begin{tabular}{|c|c|c|c|c|c|c|c|c|}
\hline FK2 & 0.406 & & & & Omitted & & & \\
\hline FK3 & 0.548 & & & & Omitted & & & \\
\hline FK4 & 0.754 & & & & 0.736 & & & \\
\hline FK5 & 0.713 & & & & 0.725 & & & \\
\hline FK6 & 0.719 & & & & 0.741 & & & \\
\hline FK7 & 0.717 & 0.424 & 0.83 & 0.777 & 0.702 & 0.506 & 0.836 & 0.760 \\
\hline FSAT1 & -0.046 & & & & Omitted & & & \\
\hline FSAT2 & 0.718 & & & & 0.709 & & & \\
\hline FSAT3 & 0.734 & & & & 0.734 & & & \\
\hline FSAT4 & 0.640 & & & & 0.646 & & & \\
\hline FSAT5 & 0.822 & & & & 0.826 & & & \\
\hline FSAT6 & 0.880 & & & & 0.881 & & & \\
\hline FSAT7 & 0.694 & 0.485 & 0.846 & 0.783 & 0.695 & 0.567 & 0.886 & 0.845 \\
\hline FSOC1 & 0.822 & & & & 0.864 & & & \\
\hline FSOC2 & 0.767 & & & & 0.759 & & & \\
\hline FSOC3 & 0.452 & & & & Omitted & & & \\
\hline FSOC4 & 0.508 & & & & 0.489 & & & \\
\hline FSOC5 & 0.852 & & & & 0.874 & & & \\
\hline FSOC6 & 0.277 & & & & Omitted & & & \\
\hline FSOC7 & 0.833 & 0.460 & 0.843 & 0.805 & 0.833 & 0.604 & 0.880 & 0.843 \\
\hline FSTR1 & 0.603 & & & & 0.555 & & & \\
\hline FSTR2 & 0.708 & & & & 0.734 & & & \\
\hline FSTR3 & 0.749 & & & & 0.764 & & & \\
\hline FSTR4 & 0.776 & & & & 0.798 & & & \\
\hline FSTR5 & 0.393 & 0.436 & 0.787 & 0.668 & Omitted & 0.517 & 0.808 & 0.682 \\
\hline
\end{tabular}


Table 1 contains loadings of all items, and average variance extracted (AVE), CR and alpha values of all constructs before and after iteration. FB4, FK2, FK3, FSAT1, FSOC3, FSOC6 and FSTR5 removed due to their low size of loadings. Initially, values of AVE were below threshold level. However, removal of the items with low loadings increased the values of AVE and alpha, thus fulfilling the minimum requirements. The internal consistency of items threshold value is 0.70 (Nunnally, 1978). The values above the threshold indicate good internal consistency (Hair, Black, Babin, Anderson, \& Tatham, 2006). The AVE cutoff values $>0.50$ and $\mathrm{CR}$ values $>0.70$ are acceptable (Fornell \& Larcker, 1981b).

Table 2.

Discriminant Validity

\begin{tabular}{|l|l|l|l|l|l|}
\hline \multicolumn{1}{|c|}{$\begin{array}{c}\text { Variable } \\
\text { Description }\end{array}$} & \multicolumn{1}{|c|}{1} & \multicolumn{1}{c|}{2} & 3 & 4 & 5 \\
\hline $\begin{array}{l}\text { Financial } \\
\text { Behavior }\end{array}$ & 0.707 & & & & \\
\hline $\begin{array}{l}\text { Financial } \\
\text { Knowledge }\end{array}$ & 0.180 & 0.711 & & & \\
\hline $\begin{array}{l}\text { Financial } \\
\text { Satisfaction }\end{array}$ & 0.354 & 0.123 & 0.753 & & \\
\hline $\begin{array}{l}\text { Financial } \\
\text { Socialization }\end{array}$ & -0.066 & -0.010 & -0.139 & 0.777 & 0.719 \\
\hline $\begin{array}{l}\text { Financial } \\
\text { Stressor }\end{array}$ & 0.069 & -0.017 & -0.155 & 0.493 & \\
\hline
\end{tabular}

Fornell and Larcker (1981a) used to test discriminant validity of the model. Table 2 contains correlation coefficients in the cells below the diagonal line while the square roots of the AVE values placed on the diagonal line. Table 2 shows that square root AVE value of each construct exceeds all values lying in the respective column and row, hence discriminant validity of the model is established.

Model Testing by using SEM

Figure 2 display the results of mediation analysis by using Smart-PLS software.

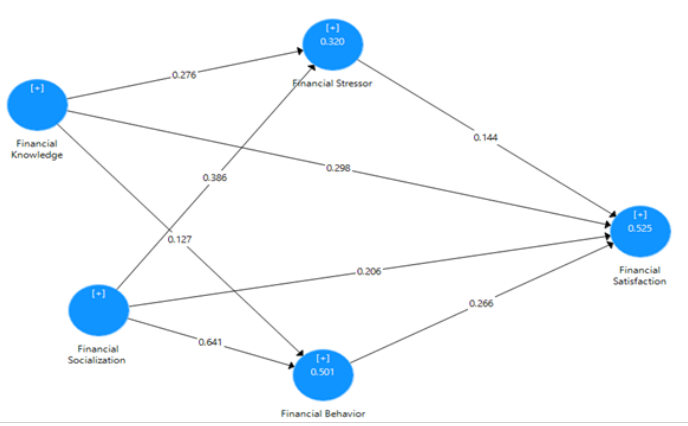

Figure 2:

SEM Model 
IBT Journal of Business Studies Volume 15(1), 2019

Table 3.

SEM Analysis

\begin{tabular}{|l|l|l|l|l|l|l|}
\hline & $\begin{array}{l}\text { Original } \\
\text { Sample }\end{array}$ & $\begin{array}{l}\text { Sample } \\
\text { Mean }\end{array}$ & $\begin{array}{l}\text { Standard } \\
\text { Deviation }\end{array}$ & T Statistics & P Values & Support \\
\hline $\begin{array}{l}\text { Financial } \\
\text { Behavior -> } \\
\text { Financial } \\
\text { Satisfaction }\end{array}$ & 0.266 & 0.265 & 0.060 & 4.461 & 0.000 & YES \\
\hline $\begin{array}{l}\text { Financial } \\
\text { Knowledge } \\
\text {-> Financial } \\
\text { Behavior }\end{array}$ & 0.127 & 0.122 & 0.059 & 2.152 & 0.045 & YES \\
\hline $\begin{array}{l}\text { Financial } \\
\text { Knowledge } \\
\text {-> Financial } \\
\text { Satisfaction }\end{array}$ & 0.298 & 0.266 & 0.128 & 2.328 & 0.020 & YES \\
\hline $\begin{array}{l}\text { Financial } \\
\text { Knowledge -> } \\
\text { Financial Stressor }\end{array}$ & 0.276 & 0.254 & 0.136 & 2.030 & 0.043 & YES \\
\hline $\begin{array}{l}\text { Financial } \\
\text { Socialization } \\
->\text { Financial } \\
\text { Behavior }\end{array}$ & 0.641 & 0.638 & 0.035 & 18.382 & 0.000 & YES \\
\hline $\begin{array}{l}\text { Financial } \\
\text { Socialization } \\
->\text { Financial } \\
\text { Satisfaction }\end{array}$ & 0.206 & 0.206 & 0.059 & 3.507 & 0.000 & YES \\
\hline $\begin{array}{l}\text { Financial } \\
\text { Socialization -> } \\
\text { Financial Stressor }\end{array}$ & 0.386 & 0.385 & 0.050 & 7.681 & 0.000 & YES \\
\hline $\begin{array}{l}\text { Financial Stressor } \\
->\text { Financial } \\
\text { Satisfaction }\end{array}$ & 0.144 & 0.146 & 0.048 & 2.992 & 0.003 & YES \\
\hline
\end{tabular}

Table 03 shows that all hypotheses supported. Financial knowledge has a positive and significant impact on financial stressor $(\beta=0.276, \mathrm{p} \leq 0.05)$. Financial knowledge has a significant and positive impact on financial satisfaction in the presence of financial stressor and financial behavior of investors $(\beta=0.298, p \leq 0.05)$. Financial stressor $(\beta=0.144, p \leq 0.05)$ and financial behavior $(\beta=$ $0.266, p \leq 0.05)$ have also positive and significant impact on financial satisfaction. The direct impact of financial knowledge on financial satisfaction is significant $(\beta=0.459, \mathrm{p} \leq 0.05)$. Some form of mediation supported if the effect of the mediating variable remains significant after controlling for the independent variable. If the independent variable is no longer significant when the mediating variable is controlled, the finding supports full mediation. If the independent variable is still significant (i.e., both independent and mediating variables both significantly predict dependent variable), the finding supports partial mediation (Baron \& Kenny, 1986; Hayes \& Scharkow, 2013; MacKinnon, Fairchild, \& Fritz, 2007). Hence, we can conclude that financial stressor and financial 
behavior partially mediatein the relationship between financial knowledge and financial satisfaction. The results also reveal that financial socialization has positive and significant impact on financial stressor $(\beta=0.386, p \leq 0.05)$. Financial socialization has significant and positive impact on financial satisfaction in the presence of financial stressor and financial behavior of investors $(\beta=0.206, \mathrm{p} \leq$ $0.05)$. Financial stressor $(\beta=0.144, p \leq 0.05)$ and financial behavior $(\beta=0.266, p \leq 0.05)$ have also positive and significant impact on financial satisfaction. The direct impact of financial socialization on financial satisfaction is significant $(\beta=0.523, \mathrm{p} \leq 0.05)$.

Table 4.

R-square Statistics

\begin{tabular}{|l|l|l|}
\hline & R Square & R Square Adjusted \\
\hline Financial Stressor & 0.320 & 0.317 \\
\hline Financial Behavior & 0.501 & 0.498 \\
\hline Financial Satisfaction & 0.527 & 0.521 \\
\hline
\end{tabular}

Table 04 presents $\mathrm{R}$ square and adjusted $\mathrm{R}$ square values of all endogenous variables included in the model. According to Cohen (1988) for a good model, the value of R square of all endogenous latent variables should exceed 0.26 . Since $\mathrm{R}$, square valuesof all endogenousvariables in the models exceed the suggested value.

Table 5.

Indirect Effect

\begin{tabular}{|l|l|l|l|l|l|}
\hline & $\begin{array}{l}\text { Original } \\
\text { Sample }\end{array}$ & Sample Mean & $\begin{array}{l}\text { Standard } \\
\text { Deviation }\end{array}$ & T Statistics & P Values \\
\hline $\begin{array}{l}\text { Financial Knowledge -> } \\
\text { Financial Satisfaction }\end{array}$ & 0.074 & 0.070 & 0.023 & 3.217 & 0.041 \\
\hline $\begin{array}{l}\text { Financial Socialization -> } \\
\text { Financial Satisfaction }\end{array}$ & 0.226 & 0.225 & 0.041 & 5.570 & 0.000 \\
\hline
\end{tabular}

Table 5 shows the results of indirect effect analysis. Itindicates that financial stressor and financial behavior have significant indirect relationship between financial knowledge, financial socialization and financial satisfaction. The resultsalso show that the relationship is significant $(\mathrm{P}<0.05)$ while the indirect effect of financial knowledge to financial satisfaction, financial socialization is also statistically significant $(\mathrm{P}<0.05)$ indirect on financial satisfaction.

\section{CONCLUSION}

The main purpose of this study to investigate the effect of financial knowledge and financial socialization on financial satisfaction with the mediating role of the financial stressor and financial behavior of the people's experienced unexpected hospitality. Based on results, we can conclude that all the predictors significantly influence their respective criterion variables and that there is a significant impact of mediation variables on the outcome's variables. 
Based on the results, financial knowledge and financial socialization has positive impact on financial stress $(\mathrm{R} 2=0.320)$. Financial knowledge and financial stressor are also influencing the financial behavior $(\mathrm{R} 2=0.501)$ and the financial stressor and financial behavior are explaining the financial satisfaction $(\mathrm{R} 2=0.527)$.

Rresultsof the study also reveal that those peoples who are in the age group of 31-40 years having no job and that is why they experienced at least two times unexpected hospital. One of the possible explanations is that the lower class is mostlyhaving joint family system, which causes more financial stress for the family. The study concludes that financial knowledge and financial socialization have low effect on financial stressor, but they have a critical role in financial satisfaction of the individuals. The main limitation of this study related to sample size. Findings of the study based on the responses of only 243 respondents. The findings of this study may not be generalizable to wider segments of population. The second limitation of the study is that analysis based on the cross-sectional study, to obtain consistent results, future studies recommended tocollect longitudinal data. It also suggestdthatthe effect of other life events such as marriage and retiring from work should also be examined. Besides, future studies may utilize other variables to measure financial satisfaction such as financial solvency, financial tolerance, and financial capability.

\section{REFERENCES}

Aboagye, J., \& Jung, J. Y. (2018). Debt Holding, Financial Behavior, and Financial Satisfaction. Journal of Financial Counseling and Planning, 29(2), 208-218. doi:10.1891/1052-3073.29.2.208

Agnew, S., Maras, P., \& Moon, A. (2018). Gender differences in financial socialization in the home-An exploratory study. International Journal of Consumer Studies, 42(3), 275-282. doi: 10.1111/ijcs. 12415

Ali, S., Lu, W., \& Wang, W. (2013). Comparison of entrepreneurial intentions among college students in China and Pakistan. International Journal of Pluralism and Economics Education, 4(1), 51-60. doi:10.1504/ijpee.2013.0535

Andrews, B., \& Wilding, J. M. (2004). The relation of depression and anxiety to life-stress and achievement in students. British Journal of Psychology, 95(4), 509-521. doi:https://doi. org/10.1348/0007126042369802

APA. (2012). Stress in America Retrieved on May 12, 2013 from http://www.apa.org/news/press/ releases/stress/2012/impact-report.pdf.

Archuleta, K. L., Dale, A., \& Spann, S. M. (2013). College Students and Financial Distress: Exploring Debt, Financial Satisfaction, and Financial Anxiety. Journal of Financial Counseling and Planning, 24(2), 50-62.

Baron, R. M., \& Kenny, D. A. (1986). The moderator-mediator variable distinction in social psychological research: Conceptual, strategic, and statistical considerations. Journal of personality and social psychology, 51(6), 1173.

Bray, J. R. (2001). Hardship in Australia: an analysis of financial stress indicators in the 1998-99 Australian Bureau of Statistics Household Expenditure Survey. FaHCSIA Occasional Paper(4).

Calvet, L. E., Campbell, J. Y., \& Sodini, P. (2007). Down or out: Assessing the welfare costs of household investment mistakes. Journal of Political Economy, 115(5), 707-747.

CFBP. (2015). Consumer Financial Protection Bureau The Financial well-being: The goal of financial education.

Cohen, J. (1988). Statistical power analysis for the behavioral sciences 2nd edn: Erlbaum Associates, Hillsdale.

Costa, D. F., Carvalho, F. d. M., \& Moreira, B. C. d. M. (2019). Behavioral Economics and 
Behavioral Finance: A Bibliometric Analysis of the Scientific Fields. Journal of Economic Surveys, 33(1), 3-24.

Davis, C. G., \& Mantler, J. (2004). The consequences of financial stress for individuals, families, and society. Centre for Research on Stress, Coping and Well-being. Carleton University, Ottawa.

Delgadillo, L. M., \& Law, R. H. (2019). Personal Finance Competencies in the Practice of Financial Counseling Financial Counseling (pp. 17-30): Springer.

Dictionary, O. Knowledge Reterived from https://en.oxforddictionaries.com/definition/knowledge.

F. Hair Jr, J., Sarstedt, M., Hopkins, L., \& G. Kuppelwieser, V. (2014). Partial least squares structural equation modeling (PLS-SEM) An emerging tool in business research. European Business Review, 26(2), 106-121.

Falahati, L., \& Paim, L. (2011). Gender differences in financial well-being among college students. Australian Journal of Basic and Applied Sciences, 5(9), 1765-1776.

Fornell, C., \& Larcker, D. F. (1981a). Evaluating structural equation models with unobservable variables and measurement error. Journal of marketing research, 18(1), 39-50.

Fornell, C., \& Larcker, D. F. (1981b). Evaluating structural equation models with unobservable variables and measurement error. Journal of marketing research, 39-50.

Gerrans, P., Speelman, C., \& Campitelli, G. (2014). The relationship between personal financial wellness and financial wellbeing: A structural equation modelling approach. Journal of Family and Economic Issues, 35(2), 145-160. doi:10.1007/s10834-013-9358-z

Gerstenecker, A., Triebel, K., Eakin, A., Martin, R., \& Marson, D. (2018). Exploring the Factor Structure of Financial Capacity in Cognitively Normal and Impaired Older Adults. Clinical Gerontologist, 41(1), 33-41. doi:10.1080/07317115.2017.1387211

Grable, J. E., \& Joo, S.-h. (2001). A further examination of financial help-seeking behavior. Journal of Financial Counseling and Planning, 12(1), 55.

Hair, J. F., Black, W. C., Babin, B. J., Anderson, R. E., \& Tatham, R. L. (2006). Multivariate data analysis (Vol. 6): Upper Saddle River, NJ: Pearson Prentice Hall.

Harding, J. (2011). Financial circumstances, financial difficulties and academic achievement among first-year undergraduates. Journal of Further and Higher Education, 35(4), 483-499. doi:https:// doi.org/10.1080/0309877X.2011.584969

Hayes, A. F., \& Scharkow, M. (2013). The relative trustworthiness of inferential tests of the indirect effect in statistical mediation analysis: Does method really matter? Psychological science, 24(10), 1918-1927.

Hayhoe, C. R., Leach, L. J., Turner, P. R., Bruin, M. J., \& Lawrence, F. C. (2000). Differences in spending habits and credit use of college students. Journal of Consumer Affairs, 34(1), 113-133.

Hira, T. K., \& Mugenda, O. (2000). Gender differences in financial perceptions, behaviors and satisfaction. JOURNAL OF FINANCIAL PLANNING-DENVER-, 13(2), 86-93.

Hira, T. K., \& Mugenda, O. M. (1998). Predictors of financial satisfaction: Differences between retirees and non-retirees. Journal of Financial Counseling and Planning, 9(2), 75.

Hira, T. K., \& Mugenda, O. M. (1999). The relationships between self-worth and financial beliefs, behavior, and satisfaction. Journal of Family and Consumer Sciences, 91(4), 76.

Hira, T. K., Sabri, M. F., \& Loibl, C. (2013). Financial socialization's impact on investment orientation and household net worth. International Journal of Consumer Studies, 37(1), 29-35.

Hsiao, Y.-J., \& Tsai, W.-C. (2018). Financial literacy and participation in the derivatives markets. Journal of Banking \& Finance, 88, 15-29. doi:https://doi.org/10.1016/j.jbankfin.2017.11.006

Hussain, A. B., \& Endut, N. (2018). Do decent working conditions contribute to work-life balance: A study of small enterprises in Bangladesh. Asia Pacific Journal of Innovation and Entrepreneurship, 12(1), 90-104.

Joo, S.-H., Durband, D. B., \& Grable, J. (2008). The academic impact of financial stress on college 
IBT Journal of Business Studies Volume 15(1), 2019

students. Journal of College Student Retention: Research, Theory \& Practice, 10(3), 287-305.

Joo, S.-h., \& Garman, E. T. (1998). Personal financial wellness may be the missing factor in understanding and reducing worker absenteeism. Personal Finances and Worker Productivity, 2(2), 172-182.

Joo, S.-h., \& Grable, J. E. (2004). An Exploratory Framework of the Determinants of Financial Satisfaction. Journal of Family and Economic Issues, 25(1), 25-50. doi:10.1023/ B:JEEI.0000016722.37994.9f

Kalra Sahi, S. (2013). Demographic and socio-economic determinants of financial satisfaction: A study of SEC-A segment of individual investors in India. International Journal of Social Economics, 40(2), 127-150. doi:10.1108/03068291311283607

Kim, J., \& Garman, E. T. (2003). Financial Stress and Absenteeism: An Empirically. Derived Model. Journal of Financial Counseling and Planning, 14(1), 31.

Kirbiš, I. Š., Vehovec, M., \& Galić, Z. (2017). Relationship between financial satisfaction and financial literacy: Exploring gender differences. Društvena istraživanja, 26(2), 165-185. doi:10.5559/di.26.2.02

Lajuni, N., Bujang, I., Karia, A. A., \& Yacob, Y. (2018). RELIGIOSITY, FINANCIAL KNOWLEDGE, AND FINANCIAL BEHAVIOR INFLUENCE ON PERSONAL FINANCIAL DISTRESS AMONG MILLENNIAL GENERATION. Jurnal Manajemen dan Kewirausahaan, 20(2), 92-98.

Lanlan, S., Xuesong, H., \& Rong, K. (2018). The Impacts of Financial Literacy on Farmers' Behavior of Farmland Transfer: An Analysis Based on the Regulatory Role of Farmland Certification. Chinese Rural Economy, 8, 002.

LeBaron, A. B., Hill, E. J., Rosa, C. M., \& Marks, L. D. (2018). Whats and Hows of Family Financial Socialization: Retrospective Reports of Emerging Adults, Parents, and Grandparents. Family Relations, 67(4), 497-509. doi:10.1111/fare.12335

LeBaron, A. B., Runyan, S. D., Jorgensen, B. L., Marks, L. D., Li, X., \& Hill, E. J. Practice Makes Perfect: Experiential Learning as a Method for Financial Socialization. Journal of Family Issues, 0(0), 0192513X18812917. doi:10.1177/0192513x18812917

Li, X., Subrahmanyam, A., \& Yang, X. (2018). Can financial innovation succeed by catering to behavioral preferences? Evidence from a callable options market. Journal of Financial Economics, 128(1), 38-65. doi:https://doi.org/10.1016/j.jfineco.2018.01.010

Lim, H., Heckman, S., Montalto, C., \& Letkiewicz, J. (2014). Financial stress, self-efficacy, and financial help-seeking behavior of college students.

Loibl, C., \& Hira, T. K. (2005). Self-directed financial learning and financial satisfaction. Journal of Financial Counseling and Planning, 16(1), 11.

MacKinnon, D. P., Fairchild, A. J., \& Fritz, M. S. (2007). Mediation analysis. Annu. Rev. Psychol., 58, 593-614.

Marks, G. (2007). Income poverty, subjective poverty and financial stress.

McCubbin, H. I., \& Patterson, J. M. (1983). The family stress process: The double ABCX model of adjustment and adaptation. Marriage \& family review, 6(1-2), 7-37.

Mugenda, O. M., Hira, T. K., \& Fanslow, A. M. (1990). Assessing the causal relationship among communication, money management practices, satisfaction with financial status, and satisfaction with quality of life. Lifestyles, 11(4), 343-360.

Newman, C., Delaney, L., \& Nolan, B. (2008). A Dynamic Model of the Relationship Between Income and Financial Satisfaction: Evidence from Ireland. Economic \& Social Review, 39(2).

Northern, J. J., O’Brien, W. H., \& Goetz, P. W. (2010). The development, evaluation, and validation of a financial stress scale for undergraduate students. Journal of College Student Development, 51(1), 79-92.

Page | 136 
Norvilitis, J. M., Szablicki, P. B., \& Wilson, S. D. (2003). Factors influencing levels of credit-card debt in College Students 1. Journal of applied social psychology, 33(5), 935-947.

Nunnally, J. (1978). Psychometric theory (2nd edit.) mcgraw-hill. Hillsdale, NJ.

Power, M. L., \& Hira, T. K. (2004). University-Provided Retirement Planning Support and Retiree Financial Satisfaction During Retirement: Differences by Gender, Job Classification, and Planning Behavior. Risk Management and Insurance Review, 7(2), 121-149.

Ranta, M., Chow, A., \& Salmela-Aro, K. (2013). Trajectories of life satisfaction and the financial situation in the transition to adulthood. Longitudinal and Life Course Studies, 4(1), 57-77.

Robb, C. A., \& Woodyard, A. (2011). Financial knowledge and best practice behavior.

Ruxyn, T. (2017). Bank Negara reveals the 4 biggest mistakes malaysians make when it comes to money.

Sahi, S. K. (2017). Psychological biases of individual investors and financial satisfaction. Journal of Consumer Behaviour, 16(6), 511-535.

Saurabh, K., \& Nandan, T. (2018). Role of financial risk attitude and financial behavior as mediators in financial satisfaction: Empirical evidence from India. South Asian Journal of Business Studies, 7(2), 207-224. doi:10.1108/sajbs-07-2017-0088

Shim, S., Barber, B. L., Card, N. A., Xiao, J. J., \& Serido, J. (2010). Financial socialization of first-year college students: The roles of parents, work, and education. Journal of youth and adolescence, 39(12), 1457-1470.

Sirgy, M. J., Yu, G. B., Lee, D.-J., \& Bosnjak, M. (2019). The Effect of Shopping Satisfaction during Leisure Travel on Satisfaction with Life Overall: The Mitigating Role of Financial Concerns.

Statistics. (2017). Planning \& Development Department. Retrieved from https://www.pndajk.gov. pk/uploadfiles/downloads/Statistical\%20Book\%202017\%20Final.pdf

Timmer, Y. (2018). Cyclical investment behavior across financial institutions. Journal of Financial Economics, 129(2), 268-286. doi:https://doi.org/10.1016/j.jfineco.2018.04.012

Totenhagen, C. J., Wilmarth, M. J., Serido, J., Curran, M. A., \& Shim, S. (2019). Pathways from Financial Knowledge to Relationship Satisfaction: The Roles of Financial Behaviors, Perceived Shared Financial Values with the Romantic Partner, and Debt. Journal of family and economic Issues, 1-15.

Wang, A. (2009). Interplay of investors' financial knowledge and risk taking. The journal of behavioral finance, 10(4), 204-213.

Wikhamn, W. (2019). Innovation, sustainable HRM and customer satisfaction. International Journal of Hospitality Management, 76, 102-110.

Xiao, J. J. (2008). Applying behavior theories to financial behavior Handbook of consumer finance research (pp. 69-81): Springer.

Xiao, J. J., Chen, C., \& Chen, F. (2014). Consumer Financial Capability and Financial Satisfaction. Social Indicators Research, 118(1), 415-432. doi:10.1007/s11205-013-0414-8

Xiao, J. J., \& O’Neill, B. (2018). Propensity to plan, financial capability, and financial satisfaction. International Journal of Consumer Studies, 42(5), 501-512. doi:doi:10.1111/ijcs.12461

Xiao, J. J., \& Porto, N. (2017). Financial education and financial satisfaction: Financial literacy, behavior, and capability as mediators. International Journal of Bank Marketing, 35(5), 805-817.

Xiao, J. J., Sorhaindo, B., \& Garman, E. T. (2006). Financial behaviours of consumers in credit counselling. International Journal of Consumer Studies, 30(2), 108-121.

Yong, C.-C., Yew, S.-Y., \& Wee, C.-K. (2018). Financial Knowledge, Attitude and Behaviour of Young Working Adults in Malaysia. Institutions and Economies, 10(4). 